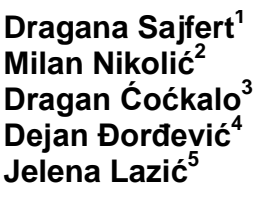

JEL: D23, J53, L20

DOI: $10.5937 /$ industrija1-7602

UDC: 005.322:316.46]:669(497.11)

Original Scientific Paper

\title{
The Leadership and Ethical Leadership in the Serbian Metal Industry ${ }^{6}$
}

\author{
Article history: \\ Received:leave 22 January 2015 \\ Sent for revision: 18 March 2015 \\ Received in revised form: 28 January 2016 \\ Accepted: 5. February 2016 \\ Available online: 1. April 2016
}

\begin{abstract}
The research conducted was intended to determine the quality of relationships and exchanges between the leaders and followers, as well as the importance of ethical leadership in metal industry of Serbia. The research has identified several significant recommendations for leaders and high level managers about what should they in particular focus on in their work. First of all, leaders need to pay attention to their employees. This means that they need to understand the problems the employees face when working, to recognize the potentials and abilities of their employees, as well as to demonstrate to employees the extent to which they are satisfied with their work. In addition, leaders need to be fair and have personal integrity. Only in this way, they can gain and maintain authority over employees.
\end{abstract}

Keywords: Leadership, Ethical leadership, Metal industry, Serbia.

\section{Liderstvo i etičko liderstvo u metalskoj industriji Srbije}

Apstrakt: Cilj istraživanja je bilo utvrđivanje kvaliteta relacija i razmene između lidera i sledbenika, kao i značaja etičkog liderstva u metalskoj

\footnotetext{
${ }^{1}$ University of Novi Sad, Technical Faculty “Mihajlo Pupin”, Zrenjanin, Serbia, PhD student

2 University of Novi Sad, Technical Faculty "Mihajlo Pupin”, Zrenjanin, Serbia,

mikaczr@sbb.rs

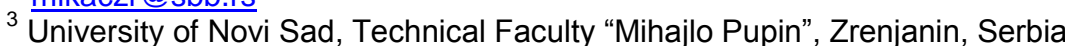

${ }^{4}$ University of Novi Sad, Technical Faculty "Mihajlo Pupin", Zrenjanin, Serbia

${ }^{5}$ Economics institute, Belgrade, Serbia

6 This paper is part of the research funded by the Government of the Republic of Serbia and the Ministry of Education Science and Technological Development. The projects (TR 35017 and $179001 \mathrm{dn}$ ) were approved for the period from 2010 to 2016.
} 
industriji Srbije. Istraživanje je identifikovalo nekoliko značajnih preporuka za lidere i menadžere višeg nivoa o tome na šta treba posebno da se fokusiraju u svom radu. Pre svega, lideri treba da obraćaju pažnju na svoje zaposlene. To znači da treba da razumeju probleme sa kojima se zaposleni susreću u radu, da prepoznaju potencijale i sposobnosti zaposlenih, kao i da pokažu zaposlenima u kolikoj meri su zadovoljni njihovim radom. Pored toga, lideri moraju da budu pravični i da poseduju lični integritet. Samo na taj način lideri mogu da steknu i zadrže autoritet kod zaposlenih.

Ključne reči: Liderstvo, Etičko liderstvo, Metalska industrija, Srbija.

\section{Introduction}

Scientific studies prove that in reality there are two basic ways of organizing. There is a natural organization, in which operation occurs naturally within the organized structure, while the second type represents a fundamental structure of organizing people. This organization is often showed as artificial, which is presented as an organization or organizational systems.

Theoretical approach to leadership as a specific set of personality characteristics holders of these functions makes the start of scientific interest and research a rather complex problem. The most notable aspect of group behavior can be seen in the fact that some people become leaders and other become followers. Some authors (Kreč \& Kračfild, 1980) argue that the main problems of leadership related to the function of a leader, stem from personality characteristics related to the "ability" to conduct and operation of the leaders in the functioning of the group. According to (Kreč \& Kračfild, 1980), the majority leader must play several roles simultaneously. Leaders take over the functions of the perpetrator, planners, builders policy experts, representatives of the external groups, supervisor of internal relations within the group, the person in charge of rewards and penalties, the umpires and intermediaries in internal disputes, the provider of good examples, father figure and when things go wrong, the sacrificial lamb. It is always an interesting question who will emerge as a leader? The leader is the one who perseveres in the group and is perceived as a person who is able to successfully lead the group to achieving their goals. According to (Sanford, 1952) members of the group, who were "authoritarian" oriented, they prefer a strict directive leadership and seek appropriate types of leaders. Based on investigations conducted in the $60 \mathrm{~s}$, Stogdil concluded that leaders increasingly demonstrate the following: 
- Lines of abilities: intelligence, ability to grasp the situation, verbal ability, the ability to adapt;

- Lines of sociability: accountability, activity, social participation, cooperation and popularity;

- Lines of motivation: initiative, perseverance, resourcefulness.

Search for leadership qualities through hundreds of studies led to a list of data that have been narrowed down to a few characteristics that showed the strongest correlation with effective leadership): intelligence, ability to solve issues, domination, confidence, energy, tolerance, integrity and behavior, emotional power (Stogdill, 1974).

As Stogdil (1974) stated that "the characteristics of leaders are: achievement, persistence, acumen, initiative, self-confidence, responsibility, cooperation, tolerance, ability to be liked, and sociability." (as cited in Northouse, 2008). Today, the researchers came to consensus about the basic factors or attributes that make up what we define as personality.

George (1992) holds that personality traits are relatively permanent features of the people that explain their behavior and allow prediction of their behavior. Understanding personality is important in many aspects, but also to us here in terms of organizational behavior of leaders. According to (Levitt, 1974), knowledge of personality characteristics linked to the obvious fact that, despite the knowledge and the desire, not everyone can be a good leader. All the present theses show that there is characteristic style of leader behavior associated with the personality of the leader. Some researchers show (Staw, 1986) that the job satisfaction is associated with something important for a person or his/her personality. More and more authors (Bas, 1981) consider that the personality traits distinguish leaders from followers, the successful from the unsuccessful leaders, top leaders from lower level leaders. Some authors (Kets de Vries \& Miller, 1986) based on the research suggest that personality itself can affect the strategy and organizational culture, but also the organizational structure. Their research shows that the need for achievement leaders considered, along with the size of the organization, has the highest correlation between structural variables, while some traditional variables, such as, technology and environment uncertainty, had little impact. It can be easily concluded that the most demanding professions have their own personality traits, which, along with the skills, contribute to personal success. 


\section{Research of leaders' traits}

This study assumed that organizations have rare individuals who possess exceptional traits, namely - qualities of leaders. Such personal characteristics according to (Mihailović \& Ristić, 2011) are attributed to only a relatively small number of people in average population and does not exceed $1 \%$. Leaders are recruited from the those individuals who possess such features. The premise of this part of the survey was that the leaders, whose characteristics are closer to the required "profile characteristic traits" are successful in their work rather than the leaders whose individual traits are less compatible with the "ideal profile" leaders.

This evaluation of leadership is usually based on the premises established at the beginning of the twentieth century and formulated by Vilsnou Frederick Taylor. Authors (Wren \& Voich, 1998) suggest dominating characteristics: Intellectual abilities, memory, education, technical skills, manual dexterity, tactfulness, energy, endurance, honesty, sound judgment and good health.

It is interesting to look at the basics of understanding of characteristic the leaders against ethical behavior as a function of their own behavioral characteristics, age and profession. The leader's influence on leader's ethics can be linked as much as it can be conditioned. The survey was conducted using the development and validation of ethical leadership in a questionnaire about their work. It is based on the theory of interviews (Kalshoven, Den Hartog, \& De Hoogh, 2011) with seven ethical leadership behaviors, namely: 1. sense of justice, 2. integrity, 3. ethical guidelines, 4. attitudes toward people, 5. separation of powers, 6 . the role of classification of tasks 7. concerns about sustainability (fairness, integrity, ethical guidance, people orientation, power sharing, role clarification). In theory exchanges the leader follower (leader-member exchange theory LMX) leadership is defined as a process in which the center is located in interaction between leaders and followers. According to the theory of LMX, the center of the process of leadership comprises the mutual relations between leaders and followers. This theory was presented to the public for the first time in 1975 (Dansereau, Gran, \& Haga, 1975). After its first release, this theory has undergone several modifications and evolutions and to this day remains equally interesting to researchers who study the process of leadership. According to (Dansereau et al., 1975) leader provides more information, influence, trust and attention to those within the guiding group than it does to those who are in the outer group. According to them, the leader is more relied upon for guidance and communication than the case with subordinates in the outer group. Contributors to the inside of the group are working in concert with the leader and the leader reciprocates. The other group generally corresponds to leader but they usually come to work just to perform their duties, and then go home. 
Our authors (Nikolić, Sajfert, \& Kreiner, 2011) did a similar research conducted through surveys in which engineers from Serbia responded to the same questions as engineers in the United States. According to (Popović, Sajfert, \& Cvijanović, 2010) management system implies an impact - it affects the manager followers. Atanasković, Sajfert and Cvijanović (2009) in their own study found that all respondents regard organizational skills as the most important trait of project managers .

An interesting issue is whether the leadership performance at different levels of management and presence of specific experiences and knowledge influence the perception and evaluation of the importance of certain characteristics that the leader should possess. Authors Bass and Steidlmeir (1999) insist that leaders must possess high moral character and be able to take care of the problems of subordinate employees.

\section{The design and implementation of the survey}

The survey consists of nine questions formulated by the principle of circling one response which reflects the respondent's opinion. Results for all nine questions are presented in tables (Table 1 to Table 9), where each table shows the results for each question. The survey was conducted in the metal industry of the Republic of Serbia in the period from June 2010 to July 2013. The survey covered six companies in the cities of Zrenjanin, Belgrade, Valjevo and Cacak. The responses to the questionnaire yielded opinions of 133 high level managers. A small number of survey responses were due to a simple reason as the survey includes specific population of high level managers in the above-mentioned companies. The respondents were high level managers because they are closest to level of leaders, and yet the number of them is considerably higher than of the leaders.

\subsection{Examination of desired behavior of leaders}

In this study we used the much quoted paper on the leader - follower exchanges (Graen \& Uhl-Bien, 1995). The theoretical development in this area has gone through many changes and improvements. The paper uses the dominant perspective to develop a new approach to nomenclature leadership but LMX considered a relationship based on a new approach to leadership. Frequently asked questions related to LMX in mentioned issue were avenues for our research.

The results of the first question (1. What is the most desirable leadership behavior at certain levels of leadership?) are shown in Table 1. Respondents were asked to mark one of the seven offered behaviors of leaders as the most 
Sajfert D. et al.: The Leadership and Ethical Leadership in the Serbian Metal Industry

important, according to their opinion. This was done for each level of leadership in particular (top, upper middle and middle leadership).

Table 1. The most preferred leadership behavior at certain levels of leadership

\begin{tabular}{|c|c|c|c|c|c|c|}
\hline \multirow{2}{*}{$\begin{array}{c}\text { Desirable behavior of } \\
\text { leaders }\end{array}$} & \multicolumn{6}{|c|}{ The level of leadership } \\
\cline { 2 - 7 } & number & $\%$ & number & Up & number & $\%$ \\
\hline $\begin{array}{c}\text { To what degree are you } \\
\text { informed on how your } \\
\text { leader is satisfied? }\end{array}$ & 33 & 24,8 & 30 & 22,5 & 18 & 13.5 \\
\hline $\begin{array}{c}\text { To what extent does your } \\
\text { leader understand your } \\
\text { work problems? }\end{array}$ & 29 & 21,8 & 31 & 23,3 & 27 & 20,3 \\
\hline $\begin{array}{c}\text { To what extent does your } \\
\text { leader recognize your } \\
\text { potential? }\end{array}$ & 20 & 15 & 19 & 14,3 & 30 & 22,6 \\
\hline $\begin{array}{c}\text { To what extent does your } \\
\text { leader want to use the } \\
\text { acquired power to help? }\end{array}$ & 17 & 12,8 & 19 & 14,3 & 27 & 20,3 \\
\hline $\begin{array}{c}\text { To what extent is leader } \\
\text { willing to pull you out of a } \\
\text { trouble even to its own } \\
\text { detriment? }\end{array}$ & 14 & 10,5 & 14 & 10,5 & 6 & 4,5 \\
\hline $\begin{array}{c}\text { To what extent do you } \\
\text { trust your leader that he } \\
\text { will protect you? }\end{array}$ & 12 & 9 & 12 & 9 & 12 & 9 \\
\hline $\begin{array}{c}\text { Describe the efficiency of } \\
\text { your working relations } \\
\text { with the leader? }\end{array}$ & 8 & 6 & 8 & 6 & 13 & 9,8 \\
\hline
\end{tabular}

As it is evident from Table 1, the high level managers think that the highest level of satisfaction is affected by how informed the leader is that the subordinates perform well (declared by 33respondents). In the second place there is the leaders' understanding of tasks with which the followers are faced (29 respondents). The third place is the leader's ability to recognize subordinates' potential (20 respondents). In the fourth place, according to the survey, respondents think that leaders want to use acquired capabilities to help them (17 respondents) to successfully perform their job.

According to the survey, the mid-level managers have a good understanding of the problems they face (31 respondents). The mid-level leaders seem to be well informed on whether they are satisfied with the performance of the tasks of their subordinates (30 respondents). Third and fourth place are shared by the recognition of subordinates' potentials and (30 respondents) and the willingness to use acquired know-how to help subordinates (19 respondents).

According to the survey, the respondents think that the most important trait is the ability to identify potential of subordinates for growth (30 respondents). 
The second place, according to the survey, is occupied by the leaders' understanding and recognition of the problems of subordinates and how the leader wants to use the power gained to help subordinates (27 respondents). The fourth place is assigned to the extent to which the respondents are informed on how the leader is satisfied with their performance (18 respondents).

\subsection{Examination of desirable traits of leaders}

Previous findings and results of this study justify the assumption that gender influences the perception and evaluation of how important desirable traits of a leader are for successful performance of its position. Leader's desirable qualities and gender was perceived by respondents in the survey as follows: 102 associates surveyed were males and 31 females. The tables indicate the results of associates of both sexes. The results of the second question (2. What are the most desirable traits of leaders?) are shown in Table 2. Respondents were asked to mark one of seven offered traits of leaders as the most important, according to their opinion. Results for this question are presented separately for male and female respondents.

Table 2. The most desirable traits of leaders, according to the male and female high level managers

\begin{tabular}{|c|c|c|c|c|}
\hline \multirow{2}{*}{ Desirable qualities of leader } & \multicolumn{3}{|c|}{ Gender of subordinates } \\
\cline { 2 - 5 } & \multicolumn{2}{|c|}{ men } & \multicolumn{2}{c|}{ women } \\
\cline { 2 - 5 } & number & $\%$ & 7 & 5,26 \\
\hline righteousness & 22 & 16,54 & 5 & 3,75 \\
\hline integrity & 19 & 14,28 & 5 & 3,75 \\
\hline ethical guidelines & 16 & 12,03 & 6 & 4,57 \\
\hline orientation to the people & 16 & 12,03 & 4 & 3,00 \\
\hline separation of powers & 14 & 10,53 & 2 & 1,50 \\
\hline the role of classifications & 10 & 7,52 & 2 & 1,50 \\
\hline concern for system & 5 & 3,75 & 31 & $23,3 \%$ \\
\hline total & 102 & $76,7 \%$ & & \\
\hline
\end{tabular}

The observed differences between male and female associates in the selection of the most desirable traits that leaders must possess, are less than expected, and statistically insignificant. It is evident from Table 2 that female associates (7 respondents or $5.26 \%$ ) and male associates regard behavior as the most desirable feature (22 respondents or $16.54 \%$ ). As further seen from Table 2, the female respondents - associates consider the attitudes toward the people (6 respondents or $4.57 \%$ ) as more important than their counterparts who consider integrity to be more highly valued feature (19 respondents or $14.28 \%$ ), while other differences are insignificant. As it can be seen from Table 2, female respondents do not differ from their male 
counterparts in the selection of the five most desirable characteristics that leaders must possess. The differences between men and women surveyed, only exist in order of preferable characteristics of leaders. Female respondents placed integrity in the 3rd and 4th place in the order of importance with ethical guidelines for desirable traits, unlike their male counterparts that placed integrity in the second place. The research indicates that for female respondents integrity seems to be diminished, or that they simply give similar meaningful significance among the top five desirable characteristics.

\subsection{Age structure of the surveyed high level managers}

As one can see, the age of high level managers has the following sequence. The results of the third question (3. How old are you?) are shown in Table 3. The research shows that high level managers under 35 are represented by only $1.5 \%$ or 2 of them. High level managers between 36 to 40 years of age represent $3 \%$ or 4 respondents, which increases the opinion of the respondents. The results show that the number of high level managers from 41 to 45 years of age have the increased participation of $24.06 \%$ or 32 managers. The research indicates that leader's participation in relation to the age of high level managers from 46 to 50 years of age increases to $48.12 \%$ or 64 of them. High level managers from 51 years and above have a share of $23.3 \%$ or 31 of them.

Table 3. Age structure of the surveyed high level managers

\begin{tabular}{|c|c|c|}
\hline Age & Number & $\%$ \\
\hline to 35 & 2 & 1,5 \\
\hline from 36 to 40 & 4 & 3 \\
\hline from 41 to 45 & 32 & 24,06 \\
\hline from 46 to 50 & 64 & 48,12 \\
\hline Over 51 & 31 & 23,3 \\
\hline total & 133 & 100 \\
\hline
\end{tabular}

In terms of age structure, high level managers do not demonstrate any significant deviations from the general attitudes. It is significant to mention that the youngest high level managers up to (35) more highly value learning and persuasion as a way of operating in the workplace rather than coercion. Their older colleagues do not share these approaches. 


\subsection{Differences between the leaders of public and private companies}

The differences between the leaders of private and public companies reflect the impact of the privatization on the management. It is assumed, that the ownership structure of companies has significant implications on attitudes and thus the behavior of the leaders. One of the reasons for privatization is precisely the expected change of leader's behavior and shift towards the adoption of values that are more compatible with the market economy. Therefore, it was interesting to see the extent to which the respondents' opinion differ about leaders in private and public enterprises.

Differentiating between the leaders of private and public enterprises was analyzed by comparison. For this purpose, all companies were divided into two groups: public and private. The group of public enterprises comprised the following: purely public and mixed enterprises where the majority is consisted of public capital. The group of private companies: purely private and mixed enterprises with the majority of private capital. The first group is the one that distinguishes leaders of private and public companies' attitudes about the importance of certain characteristics of leaders. These differences can be seen in Table 4.

The results of the fourth question (4. What are the most desirable characteristics of leaders?) are shown in Table 4. The respondents were asked to mark one out of four characteristics of leaders that are the most important, according to their opinion. Results for this question are presented separately for respondents coming from public and private companies.

As it can be seen, the leaders of public companies value patience, composure and consistency more than their counterparts in private companies. On the other hand, leaders in private companies value charisma of a leader significantly more than leaders in public companies. If we start from the assumption that people appreciate more those qualities which they themselves possess it can be concluded that the leaders in public companies are more patient and more consistent than the leaders of private companies. At the same time, it can be said that the leaders of public companies tend to have more charisma than leaders of public companies. It is also possible that the leaders of private enterprises value charisma more because the owners of these companies have usually charismatic personality. It seems that these results confirm the widely accepted view that the leaders of public companies are more stable and inert and react slower compared to the leaders of private companies. The leaders of public companies value consistency more as a measure of their performance than the leaders of private companies where this feature is much less important. 
Sajfert D. et al.: The Leadership and Ethical Leadership in the Serbian Metal Industry

Table 4. Differentiating characteristics of leaders in private and public companies

\begin{tabular}{|c|c|c|}
\hline Characteristics of leaders & Private companies & Public companies \\
\hline Charisma & $32 \%$ & $18 \%$ \\
\hline Patience & $22 \%$ & $28 \%$ \\
\hline Composure & $23 \%$ & $27 \%$ \\
\hline Consistency & $23 \%$ & $27 \%$ \\
\hline Total & $100 \%$ & $100 \%$ \\
\hline
\end{tabular}

A possible explanation of these differences is a greater orientation of a leader in public companies to the size that is inherited from the planned economy in which the right size is regarded as an indicator of success. Another source of difference in the treatment of size as a measure of leader's success is the greater orientation of a leader in private companies to profit as the most important criterion for success.

\subsection{Knowledge of leaders about technology, production and development}

The results of the fifth question (5. What are the most desirable knowledges of leaders?) are shown in Table 5. The respondents were asked to mark one of three areas of knowledge as the most important for leaders, in their opinion. Results for this question are presented separately for respondents coming from large, medium and small companies.

The respondent associates have the opinion that leaders possess knowledge about technology in the next relation. According to the survey the associates gave the opinion that leaders possess $17 \%$ of knowledge about technology in large companies, $11 \%$ in medium-sized companies, and $7 \%$ in small companies.

At large companies the respondents think that leaders have $8 \%$ of knowledge about production, $15 \%$ of knowledge at medium sized companies, and $11 \%$ of knowledge about production at small companies. According to the respondents, leaders have the highest knowledge about research and development in large companies $14 \%, 10 \%$ in medium companies, and $7 \%$ in small companies.

Table 5. The most desirable knowledge of leaders, by company size

\begin{tabular}{|c|c|c|c|c|}
\hline $\begin{array}{c}\text { Knowledge of } \\
\text { leaders }\end{array}$ & $\begin{array}{c}\text { Large } \\
\text { companies }\end{array}$ & $\begin{array}{c}\text { Medium } \\
\text { companies }\end{array}$ & $\begin{array}{c}\text { Small } \\
\text { companies }\end{array}$ & $\%$ \\
\hline About technology & $17 \%$ & $11 \%$ & $7 \%$ & $35 \%$ \\
\hline About production & $8 \%$ & $15 \%$ & $11 \%$ & $34 \%$ \\
\hline $\begin{array}{c}\text { About research } \\
\text { and development }\end{array}$ & $14 \%$ & $10 \%$ & $7 \%$ & $31 \%$ \\
\hline Total & $39 \%$ & $36 \%$ & $25 \%$ & $100 \%$ \\
\hline
\end{tabular}




\subsection{Formal education of the surveyed high level managers}

It is not possible to put an equal sign between educational attainment and levels of formal education of leaders. It is known that leaders are educated also outside the average education system and this implies that a certain level of education is assumed to be sufficient for the exercise of leadership functions. We believe that educational background may be taken as a sufficient indicator of general education of leaders. Strong development in the field of knowledge about technology, manufacturing and research and development implies adequate education of leaders. According to the results of the survey university degree and specialization are enough to perform the function of a leader.

The results of the sixth question (6. What is your level of education?) are shown in Table 6. So, Table 6 presents the results of the research on the highest level of education of the surveyed high level managers. Educational level of the surveyed high level managers, looking through formal education, is quite high. Even $53.38 \%$ of the surveyed high level managers graduated from faculty (BSc), 71 of them. $40.60 \%$ have specialization, or numerically 54 of them, while $4.5 \%$ have a Master of Science degree, so 6 of them. A PhD degree is obtained by just $1.5 \%$ of the leaders. Based on this survey results it can be concluded that the high level managers in the surveyed companies are adequately trained.

Table 6. Formal level of the education of the surveyed high level managers

\begin{tabular}{|c|c|c|}
\hline Answer & Number & $\%$ \\
\hline Faculty (BSc) & 71 & 53,38 \\
\hline Specialization & 54 & 40,60 \\
\hline M.Sc. & 6 & 4,5 \\
\hline PhD & 2 & 1,5 \\
\hline Total & 133 & 100 \\
\hline
\end{tabular}

\subsection{Profession of the surveyed high level managers}

A very important question about managing, its development and success is the question about the profession that a leader and high level managers should have. What is the required degree that someone who would like to become a leader should have? Do some institutions (universities, colleges, academies) provide the necessary knowledge and skills for business leadership and its successful performance? A leader's and manager's job is very complex, and there are different ways and knowledge needed to solve problems of leadership. This research addresses these dilemmas. Leadership incorporates elements of science, skill and knowledge. Can all of these things be found in one person? We have to say for sure that there is no such person. 
The results of the seventh question (7. What is your profession?) are shown in Table 7 . When it comes to professional or study program, a large part of the surveyed high level managers has a degree in economic sciences $(37.59 \%)$, or 50 of them. They are followed by high level managers who have a degree in technical sciences (32.33\%), or 43 of them. A separate analysis would be needed here to find out why the high level managers with degree in economic sciences are so dominant. Next in the number of represented among the surveyed high level managers are lawyers (15.03\%), or 20 of them. There are $15 \%$ of surveyed high level managers who have a diploma from the Faculty of Organizational Sciences, or 16 of them. Finally, this study included others (3\%) or 4 respondents.

A comparison with the research in the world can be made. Deutschman (1992) states that in the USA a large number of leaders have diplomas and specializations in Business Administration (MBA), while in Germany technical education dominates. They claim that $54 \%$ of the leaders in the governing boards of the 100 largest German companies have PhD in engineering and natural sciences.

Table 7. Research about leader's profession

\begin{tabular}{|c|c|c|}
\hline Profession & Number & $\%$ \\
\hline Economic Sciences & 50 & 37,59 \\
\hline Technical Sciences & 43 & 32,33 \\
\hline Legal Sciences & 20 & 15,03 \\
\hline Organizational Sciences & 16 & 12,03 \\
\hline Other & 4 & 3 \\
\hline Total & 133 & 100 \\
\hline
\end{tabular}

\subsection{Research according to the existence of the companies}

Dafft (1992) argues that the crisis with which the company is facing in certain phases of its life cycle is related to management and leadership. Successful entrepreneurs do not have to be capable leaders, and leaders are sometimes not ready to delegate business to their associates, and thus stifling initiative, and the need to revitalize the company, but also by changing the leader, as the previous administration did what it could (Dafft, 1992).

Table 8. Research according to the existence of the companies

\begin{tabular}{|c|c|c|}
\hline Existence structure & Number & $\%$ \\
\hline Under 2 years & - & - \\
\hline $2-5$ years & 1 & 16,67 \\
\hline $6-10$ years & 1 & 16,67 \\
\hline $11-20$ years & 1 & 16,67 \\
\hline Over 20 years & 3 & 50,00 \\
\hline Total & 6 & 100 \\
\hline
\end{tabular}


The results of the eighth question (8. How many years does your company exist?) are shown in Table 8. Respondents were asked to mark one of the five possible answers.

As it can be seen from Table 8, the existence structure of the analyzed companies shows that most companies work over 20 years $(50.00 \%)$, followed by businesses working from 11 to 20 years (16.67\%), then 6-10 years $(16.67 \%)$, and then by groups with 2 to 5 years of working experience (16.67\%). There are no companies working less than 2 years. Based on these results we can conclude that Serbia has more companies with greater working experience than companies that work only few years.

\subsection{Examination of the importance of measuring ethical behavior of leaders}

Aronson (2001) discusses two main ethical theories and the ways they are related to transactional leadership styles. According to Bowie (1991) a leader will be required to act in the interests of others, even when it contradicts his/her own interests. He further stated whether it was a group work, organizations aspirations or projects in the community, leaders engage followers who are making efforts to achieve common goals. In all these situations, leaders have an ethical responsibility to treat the followers with dignity and respect - as human beings with simple identities. According to Bowie (1991) this means that leaders must respect the interests, needs and conscience of the followers.

The values promoted by the leader have a significant impact on the values that the organization presents (Carslson \& Perrewe, 1995; Schminke, Ambrose, \& Noel, 1997; Trevino, 1986). Ronald Heifetz (1994) has formulated a unique perspective on ethical leadership; it emphasizes how leaders help followers to confront conflicts and they influence the changes that occur on the basis of the conflict. According to (Heifetz, 1994) it is associated with ethical leadership as it relates to value: the value of workers and value of the organization and the community in which they work. According to Heifetz, leadership involves the use of authority in order to help the followers with the conflict situations that result from rapidly changing work environment and culture of the society. In his central thesis, Burns (1978) observes that from the terms of power, the leader must make a special relationship with the followers.

Northouse (2008) believes that in the early 70 s of the last century, Greenleaf developed a somewhat paradoxical approach to leadership called leadership in the service of others (servant leadership), which has become popular in recent years. Greenleaf (1977) argued that leadership is intended for persons who by nature serve others. In fact, a person grows into a leader by first 
serving others. A leader is in the service of others, focuses on the needs of the followers and helps them become more competent, free, independent and accommodating, like themselves. They enrich others with their presence. In recent years, the government increased interest in the study of leadership in service of others (Farling, Stone, \& Winston, 1999; Russel \& Stone, 2002; Sendjaya \& Sarros, 2002). Ideas that these scientists present in many ways resemble and agree with the ethics of caring that are processed by Gilligan (1982). He emphasized that personal relations should be the starting point of ethics and argued that issues of fairness must deal with all the people who work together to promote common interests.

According to Bass and Steidlmeir (1999) transformational leadership must be based on moral grounds. According to them these four components are authentic for transformational leadership (idealized influence, inspirational motivation, intellectual stimulation and individualized consideration).

According to Collins, Burrus and Meyer (2014) subordinates generally prefer a quality relationship with their leaders. Stouten et all. (2013) write in their paper about the deviance of leadership, but in their study they found out that at high levels, ethical leadership leads to a reduction in these behaviors.

Individually ethics of leaders according to our survey have the following sequence:

The results of the ninth question (9. What is the most important dimension of ethical behavior of leaders?) are shown in Table 9. Respondents were asked to mark one of the seven dimensions of ethical behavior of leaders as the most important, according to their opinion.

This part of the research about ethics of leadership is based on work by Kalshoven, Den Hartog and De Hoogh (2011) with seven ethical leadership behavior, namely: 1 . Fairness, 2. Integrity, 3. Ethical guidelines, 4. Orientation to people, 5. Separation of powers, 6. The role of classification and 7 . Concern for sustainability.

Table 9. The importance of some dimensions of ethical behavior of leaders

\begin{tabular}{|c|c|c|}
\hline Leadership behavior & Number & $\%$ \\
\hline Fairness & 26 & 19,54 \\
\hline Integrity & 24 & 18,04 \\
\hline Ethical guidelines & 22 & 16,54 \\
\hline Orientation to people & 18 & 13,53 \\
\hline Separation of powers & 16 & 12,03 \\
\hline The role of classification & 14 & 10,52 \\
\hline Concern for sustain. & 13 & 9,77 \\
\hline Total & 133 & 100 \\
\hline
\end{tabular}


The respondents gave the following answers: Fairness $19.54 \%$ or 26 respondents; Integrity $18 \%$ or 24 respondents; Ethical guidance $16,54 \%$ or 22 respondents; Orientation to humans $13,53 \%$ or 18 respondents; Separation of powers $12 \%$ or 16 respondents; The role of classification $10.52 \%$, or 14 respondents; The concern for sustainability $9.77 \%$, or 13 respondents.

\section{Conclusion}

The survey was conducted in the metal industry of the Republic of Serbia in the period from June 2010 till July 2013. The survey covered six companies in Zrenjanin, Belgrade, Valjevo and Cacak. The answers to the questionnaire were provided by 133 high level managers. There was a small number of respondents because the survey includes specific population in the abovementioned companies. The conducted research and the conclusions are presented.

Serbian metal industry is in a very difficult position. Through objective to mitigate adverse implications on the management of business processes, responsibility is accepted for the interaction of leaders and the followers, which has a positive effect on profitability. In principle, the motives for implementing the paradigm of leadership ethics could be: tangible and intangible. Implementation of the policy leadership ethics may be voluntary, but coerced by business partners that cooperation conditional on applying the paradigm of leadership ethics throughout the vertical management. Intangible motives are striving to increase the reputation of the company, improvement and development of leadership ethics. In long term intangible motives of leadership ethics have material consequences. Research confirms that investors prefer investing in companies that have a well-developed leaderfollower relationship.

It is evident from Table 1, that the highest level of leaders is to a great extent informed on how pleased they are with the followers, the second is the leaders' understanding about the followers' problems. In the third place for the leaders of the highest level is the recognition of the potential of their followers. Leaders of the upper secondary level have understanding for the problems of their followers, leaders are informed whether they are satisfied with the followers and leaders recognize the potential of followers and leaders' readiness to use acquired power to help followers. For the leaders of the middle level in the opinion of respondents, in the first place is to identify potential of followers. In the second place according to the research is to understand the problems of the followers. In the third place is the willingness of leaders to use the acquired power and help followers. 
Female respondents consider the orientation to the people much more important than their male colleagues who valued more the integrity of leaders. The differences among the surveyed men and women, exists only in the order of preference of leaders' traits. Female respondents place integrity on the 3rd and 4th place in order of importance about leaders' qualities, unlike their male counterparts who put integrity on the second place.

The respondents from social companies value patience, composure and consistency of their counterparts more than in private companies. The respondents in private companies value charisma significantly more than in social companies.

The research has identified several significant recommendations for leaders and high level managers to what they should in particular focus in their work. First of all, leaders need to pay attention to their employees. This means that they need to understand the problems that the employees have at work, to recognize the potentials and abilities of employees, as well as to demonstrate to employees the extent that they are satisfied with their work. In addition, leaders need to be fair and to have personal integrity. Only in this way they can gain and maintain authority over employees. Otherwise, there will be a decrease of satisfaction and motivation of employees. From this conclusion, it is clear that the behavior and characteristics of leaders have direct and indirect impact on the business performance of the company.

The analyzed relations between leaders and followers are an incentive to other metal processing industries to follow them at the same path. The paper shows how a realized project contributes to increasing cooperation between leaders and followers. In doing so, the largest effects are expected in the following years. Having in mind the current crisis, the presented research would not yield reliable results. On the other hand, in view of the increasing importance given to cooperation with Russia and the EU, we should expect that foreign companies will increase cooperation between leaders and followers.

\section{References}

Aronson, E. (2011). Integrating Leadership Styles and Ethical Perspectives. Canadian Journal of Administrative Sciences, 18(4), 244-25.

Atanasković, P., Sajfert, D., \& Cvijanović, S. (2009). The study of the role and tasks of project managers. Industry, 37(2), 127-139. (in Serbian)

Bass, B.M., \& Steidlmeir, P. (1999). Ethics, character, and authentic transformational leadership behavior. Leadership Quarterly, 10(2), 181-217. Bass, B.M. (1981). Handbook of Leadership: Theory, Research and Managerial Implications. (3rd ed.). New York: The Free Press. 
Bowie, N.E. (1991). Challenging the egoistic paradigm. Business Ethics Quarterly, $1(1), 1-21$.

Burns, J.M. (1978). Leadership. New York: Harper \& Row.

Carlson, D.S., \& Perrewe, P.L. (1995). Institutionalization of organizational ethics through international leadership. Journal of Business, 14(10), 829-838.

Collins, B., Burrus, C., \& Meyer, R. (2014). Gender differences in the impact of leadership styles on subordinate embeddedness and satisfaction. Leadership Quarterly, 25(4), 660-671.

Dafft, R. (1992). Organization Theory and Design. (4th ed.). West Publishing Company: Sant Paul.

Dansereau, F., Gran, G.B., \& Haga, W.A. (1975). Vertical dyad linkage approach to leadership in formal organizations. Organizational Behavior and Human Performance, 13, 46-78.

Deutschman, A. (1992). The CEO Secret of Managing Time, Fortune, June, 1, 135 146.

Farling, M.L., Stone, A.G., \& Winston, B.E. (1999). Servant leadership: Setting the stage for stage for empirical research. Journal of Leadership Studies, 6(1-2), 4972.

George, J.M. (1992). The Role of Personality in Organizational Life: Issues and Evidence, Journal of Management, 18 (20), 185-213.

Gilligan, C. (1982). In a different voice: Psychological Theory and Women's Development. Cambridge, MA: Harvard University Press.

Graen, G.B., \& Uhl-Bien (1995). Relationship-based Approach to Leadership: Development of Leader-Member Exchange (LMX) Theory of Leadership Over 25 Yars: Applying a Multi-Level, Multi-Domain Perspective, Leadership Quarterly, 6(2), 219-247.

Greenleaf, R.K. (1977). Servant leadership: A journey into the nature of legitimate power and greatness. New York: Paulist Press.

Heifetz, R.A. (1994). Leadership without easy answers. Cambridge, MA: Harvard University Press.

Kalshoven, K., Den Hartog, D., \& De Hoogh, A. (2011). Ethical leadership at work questionnaire (ELW): Development and validation of a multidimensional measure, Leadership Quarterly, 22(1), 51-69.

Kets de Vries, M.F.R., \& Miller, D. (1986). Personality, Culture and Organization. Academy of Management Review, 11, 266.269.

Kreč D., \& Kračfild R. (1980). Elements of psychology, Scientific Book: Belgrade. (in Serbian)

Levit, T. (1974). The managerial marry go round. Harvard Business Review, 52(4), 120-128.

Mihailović, D., \& Ristić, S. (2011). Leadership competencies, University of Belgrade, Faculty of Organizational Sciences. (in Serbian)

Nikolić, M., Sajfert, Z., \& Kreiner, J. (2011). Comparison of professional improvement and current knowledges of mechanical engineers in the USA and Serbia, Industrija, 39(1), 87-98.

Northouse, P.G. (2008). Leadership Theory and Practice, Belgrade: Data Status (in Serbian)

Popović, B., Sajfert, D., \& Cvijanović, S. (2010). The survey management system. Industry, 38(2), 81-90. (in Serbian) 
Sajfert D. et al.: The Leadership and Ethical Leadership in the Serbian Metal Industry

Russell, R.F., \& Stone, A.G. (2002). A review of servant leadership attributes: Developing a practical model. Leadership \& Organizational Development Journal, 23(3), 145-157.

Sanford, F.H. (1952). Reserch on military leadership. In Glangan, J. C. (ed). Psihology in the world emergency, Pittsburgh: Univ. of Pittsburg Pres. 17-74.

Schminke, M., Ambrose, M.L. \& Noel, T.W., (1997). The effect of ethical frameworrks on perceptions of organizational justice. Academy of Management Journal, 40(5), 1190-1207.

Sendjaya, S., \& Sarros, J.C. (2002) Servant leadership: Its origin, development and application in organizations. Journal of Leadership and Organization Studies, 9(2), 57-64.

Staw, B.M. (1986). The Dispositional approach to Job Attitudes: A Life Time Longitudinal Test. Administrative Science Quarterly, 31, 56-77.

Stogdill, R.M. (1974). Handbook of leadership research: A survey of theory and research. Riverside, NJ: Free Press.

Stouten, J., van D., Marius, M., David, M., De Cremer, D., \& Euwema, M., C. (2013). Can a leader be seen as too ethical? The curvilinear effects of ethical leadership. Leadership Quarterly, 24(5), 680-695.

Trevino, L.K. (1986). Ethical decision making in organizations: A person-situation integrationist model. Academy of Management Review, 11(3), 601-617.

Wren, D., \& Voich, D. (1998). Management - The process, structure, behavior, Commercial System. Belgrade: Grmeč. (in Serbian) 